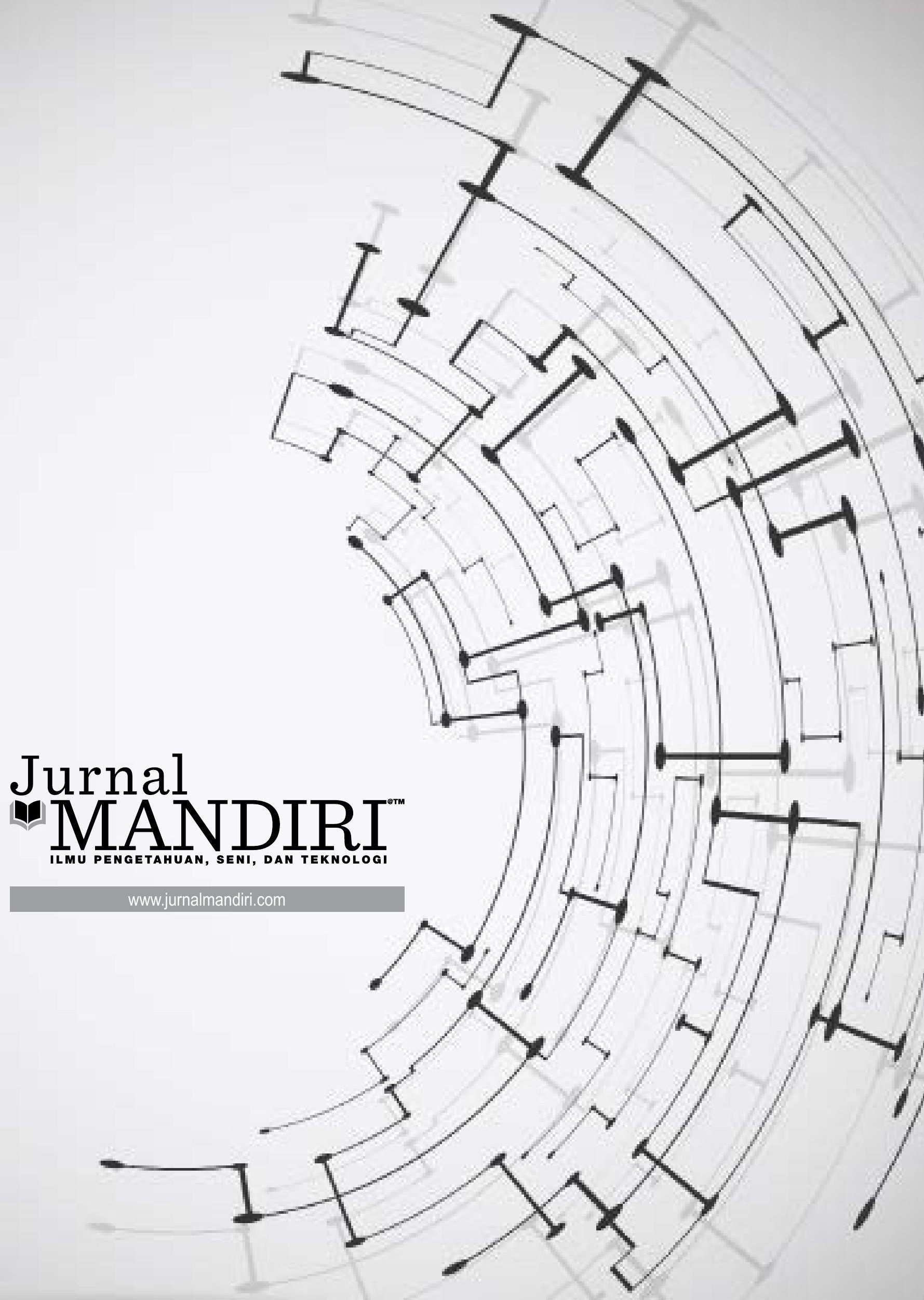


ISSN : 2580-3220, E-ISSN : 2580-4588

J. Mandiri., Vol. 1, No. 1, Juni 2017 (1 - 7)

(C)2017 Lembaga Kajian Demokrasi

dan Pemberdayaan Masyarakat (LKD-PM)

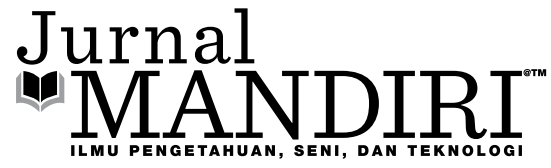

\title{
KONTRIBUSI PEMBERIAN KREDIT DAN KEMAMPUAN MANAJERIAL TERHADAP TINGKAT PENDAPATAN UKM DI KOTA MADIUN 2015
}

\author{
Aditya Pratama \\ Dosen Universitas Pamulang \\ Email:aditya.pratama.999999@gmail.com
}

\begin{abstract}
ABSTRAK
Latar Belakang: Perkembangan persaingan sebuah usaha semakin lama semakin ketat diikuti dengan perkembangan perekonomian yang ada. Pemberian kredit dan kemampuan manajerial diduga merupakan variabel yang memiliki kontribusi dengan tingkat pendapatan. Tujuan penelitian ini adalah menganalisis kontribusi pemberian kredit dan kemampuan manajerial terhadap tingkat pendapatan UKM di Kota Madiun. Metode: Penelitian ini merupakan penelitian deskriftif kuantitatif. Populasi penelitian ini adalah seluruh UKM pada tiga kecamatan di Kota Madiun sebanyak 113 UKM, sedangkan sampel penelitian ini diambil sebanyak 90 UKM. Sampel tersebut diambil dengan teknik propotionate stratified random sampling. Teknik pengumpulan data menggunakan angket dan dokumentasi. Teknik analisis data pada penelitian ini adalah dengan menggunakan regresi linier berganda. Hasil: Berdasarkan uji hipotesis dibuktikan bahwa: (1) Terdapat kontribusi pemberian kredit terhadap tingkat pendapatan UKM (2) Terdapat kontribusi kemampuan manajerial terhadap tingkat pendapatan UKM (3) terdapat kontribusi pemberian kredit dan kemampuan manajerial terhadap tingkat pendapatan UKM. Dengan demikian dapat disimpulkan bahwa pemberian kredit dan kemampuan manajerial berkontribusi langsung terhadap tingkat pendapatan UKM di Kota Madiun.
\end{abstract}

Kata Kunci: Pemberian Kredit, Kemampuan Manajerial dan Diferensiasi Produk Tingkat Pendapatan UKM.

\section{PENDAHULUAN}

Perkembangan persaingan sebuah usaha semakin lama semakin ketat diikuti dengan perkembangan perekonomian yang ada. Berdasarkan data Badan Pusat Statistik (BPS) di Indonesia jumlah Usaha Mikro Kecil dan Menengah (UMKM) tahun 2014 sebanyak 57,89 juta unit. Jumlah tersebut diperkirakan akan meningkat setiap tahunnya. Peningkatan jumlah UMKN tidak terlepas dari peningkatan jumlah angkatan kerja setiap tahunnya yang tidak diimbangi oleh penambahan lapangan kerja yang dilakukan oleh pemerintah.

Berdasakan sumber dari Kementerian Perindustrian kontribusi sektor UMKM terhadap Produk Domestik Bruto (PDB) meningkat dari $57,84 \%$ menjadi $60,34 \%$ dalam lima tahun terakhir. Serapan tenaga kerja pada sektor ini juga meningkat dari 96,99\% menjadi 97,22\% pada periode yang sama. Kontribusi sektor UMKM terhadap ekspor Indonesia tahun 2015 hanya 15,8\%, jauh lebih kecil dibandingkan 
dengan Negara-negara di kawasan Asia Tenggara seperti di Thailand dan Filipina kontribusi sektor UMKM terhadap ekspor 29,5\% dan Filipina 20\%.

Di Indonesia terdapat salah satu kota yang terkenal dengan perdagangan dan perindustrian. Kota Madiun merupakan kota yang terkenal dengan julukan Kota Gadis yang memiliki arti perdagangan dan perindustrian. Kota Madiun memiliki jumlah UMKM tergolong kedalam jumlah yang banyak. Berdasarkan data di Dinas Perindustrian, Perdagangan, Koperasi, dan Pariwisata (Disperindagkoppar) Kota Madiun hingga akhir tahun 2014, secara keseluruhan sebanyak 22.792 usaha, 90 persennya didominasi usaha mikro. Namun, pernyataan dari Kepala Disperindagkoppar Kota Madiun, Totok Sugiharto melalui Kabid Koperasi dan UMKM, Heri Wasana yang mengatakan, petugas juga kesulitan untuk melakukan pendataan terhadap banyaknya UMKM yang tidak bertahan lama atau fluktuatif. Karena itu, tahun ini UMKM akan menjadi fokus pembinaan Disperindagkoppar Kota Madiun.

Jumlah UMKM di Kota Madiun selalu mengalami fluktuasi bisa jadi dikarenakan ketidak mampuan pengelolaan maupun modal yang dimiliki pelaku UMKM. Namun, terlepas dari kepastian jumlah UMKM yang ada di kota Madiun tetap saja pelaku UMKM memberikan kontribusi terhadap PDB. Kontribusi sektor UMKM terhadap PDB tidak terlepas nilai barang dan jasa yang dihasilkan oleh UKM dalam satu tahun tertentu. Nilai barang maupun jasa yang dihasilkan oleh UMKM merupakan gambaran awal tentang kemampuan UMKM dalam permodalan maupun kemampuan dalam pengelolaan suatu usaha. Nilai barang maupun jasa yang dihasilkan oleh UMKM juga mampu menggambarkan tingkat pendapatan yang diperoleh.

Tingkat pendapatan bisa mencermikan keberasilan suatu usaha, melalui tingkat pendapatan juga dapat dilihat berapa banyak nilai barang maupun jasa yang telah dihasilkan. Jumlah produk maupun jasa yang dihasilkan tidak telepas dari jumlah modal yang dimiliki suatu unit usaha. Modal inilah yang menjadi kendala dalam pengembangan sebuah UMKM. Kendala keterbatasan permodalan yang dimiliki oleh UMKM dapat terpecahkan melalui bantuan kredit usaha yang diberikan oleh lembaga keuangan seperti koperasi.

Ikatan Akuntan Indonesia (IAI, 2007: 31) menyatakan bahwa, "Kredit adalah peminjaman uang atau tagihan yang dapat dipersamakan dengan itu berdasarkan persetujuan atau kesepakatan pinjam-meminjam antara bank dan pihak lain yang mewajibkan pihak peminjam untuk melunasi utangnya setelah jangka waktu tertentu dengan jumlah bunga, imbalan, atau pembagian hasil keuntungan".

Menurut Undang-undang No.10/1998 pasal 21 ayat 11 dalam Firdaus dan Ariyanti (2004: 1) menyatakan bahwa kredit adalah penyediaan uang atau tagihan yang dapat dipersamakan dengan itu, berdasarkan persetujuan atau kesepakatan pinjam meminjam antara bank dengan pihak lain yang mewajibkan pihak peminjam untuk melunasi utangnya setelah jangka waktu tertentu dengan pemberian bunga. Berdasarkan pendapat di atas kredit merupakan kegiatan penyaluran dana yang yang antara pemilik modal dan peminjam modal berdasarkan kententuan yang sudah disepakati.

Pemberian kredit yang diberikan oleh bank umum atau bank perkreditan rakyat memiliki berbagai jenis-jenis kredit. Jenis-jenis ini bisa mempengaruhi jumlah dana pinjaman yang akan diterima oleh kreditur. Menurut Kuncoro dan Suhardjono (2011: 206) bahwa pengelompokan kredit dapat dibedakan sebagai berikut:

a. Kredit modal kerja (KMK) adalah fasilitas kredit yang dipergunakan untuk membiayai aktiva lancar dan atau menggantikan hutang dagang, serta membiayai sementara kegiatan operasional rutin perusahaan.

b. Kredit transaksi khusus, adalah fasilitas kredit yang hanya sekali pakai yang disetujui untuk suatu tujuan atau beberapa tujuan tertentu. 
c. Kredit tidak langsung (kontijen) adalah kredit yang tidak memerlukan disposisi dana secara langsung pada saat kredit tersebut disetujui.

d. Kredit investasi adalah fasilitas kredit yang diberikan untuk membantu pembiayaan pemohon dalam memperoleh barang modal selain tanah yang tercermin dalam aktiva tetap perusahaan.

e. Kredit konsumtif adalah kredit yang memberikan untuk membiayai kebutuhan konsumtif yang diperlukan pemohon dan sumber pembayaran kembali kreditnya berasal dari penghasilan/gaji pemohon.

Uraian di atas merupakan jenis-jenis dari kredit. Tidak hanya kredit saja yang mempunyai berbagai macam jenis. Pemberian kredit pun memiliki tujuan-tujuan yang berbeda tergantung dengan posisi apakah sebagai kreditur, debitur maupun masyarakat umum. Berikut ini merupakan pendapat dari Tjoekam (2003: 3) tentang perbedaan dari tujuan kredit dari satu pihak ke pihak yang lain.

a. Tujuan kredit bagi kreditur: 1) Perkreditan merupakan sumber utama pendapatan, 2) Pemberian kredit merupakan perangsang pemasaran produk-produk lainnya dalam persaingan, 3) Perkreditan merupakan instrumen menjaga likuiditas, solvabilitas, dan profitabilitas bank.

b. Tujuan kredit bagi debitur: 1) Kredit berfungsi sebagai sarana untuk membuat kegiatan usaha semakin lancar, performance usaha semakin baik dari sebelumnya, 2) Kredit meningkatkan minat berusaha dan keuntungan sebagai jaminan kelanjutan kehidupan perusahaan, 3) Kredit memperluas kesempatan berusaha dan kerja dalam perusahaan.

c. Tujuan kredit bagi masyarakat: 1) Kredit dapat mengurangi pengangguran karena dapat membuka peluang usaha kerja dan pemerataan pendapatan, 2) Kredit dapat meningkatkan fungsi pasar karena ada peningkatan daya beli.
Lembaga peminjaman uang tidak hanya bank umum tetapi ada lembaga lain yang memberikan pinjaman uang untuk modal usaha salah satu contonya ialah koprasi. Menurut Cheruiyot, Kimeli, Ogendo (2012), kredit koperasi mempunyai peran penting dalam pengembangan masyarakat dengan memberikan pinjaman untuk tujuan produktif dan kesejahteraan. Program bantuan modal usaha melalui kredit sudah mulai banyak dilakukan di setiap daerah di Indonesia.

Pemberian kredit kepada calon peminjam tidakserta merta diberikan begitu saja.Pemberian kredit harus melewati tahapan-tahapan yang telah ditentukan oleh lembaga keuangan. Setelah tahapan tersebut terlewati baru kreditur bisa memperoleh dana dari pemberian kredit oleh debitur. Berikut ini merupakan tahapan yang dipergunakan dalam menunjang analisis untuk penentuan pemberian kredit, analisis ini ialah 5 C kredit pemohon, yaitu Character, Capacity, Capital, Condition, dan Collateral (Kuncoro dan Suhardjono, 2011: 227).

a. Analisis character bertujuan untuk mendapatkan gambaran akan kemauan membayar dari pemohon, mencakup perilaku pemohon sebelum dan selama permohonan kredit diajukan.

b. Analisis capacity dilakukan dengan tujuan untuk mengukur tingkat kemampuan mengembalikan kredit dari usaha yang dibiayai, mencakup aspek manajemen, aspek produksi, aspek pemasaran, aspek personalia, dan aspek finansial.

c. Analisis capital yang bertujuan untuk mengukur kemampuan pemohon dalam menyediakan modal sendiri, yang mencakup besar dan komposisi modal, perkembangan laba usaha selama tiga periode sebelumnya.

d. Analisis condition bertujuan untuk mengetahui prospektif atau tidaknya suatu usaha yang akan dibiayai, yang meliputi siklus bisnis mulai dari bahan baku, pengolahan, dan pemasaran.

e. Analisis collateral bertujuan untuk mengeta- 
hui besarnya nilai agunan yang dapat dipergunakan sebagai alat pengaman lapis kedua bagi bank dalam setiap pemberian kredit apabila kredit yang diberikan menjadi bermasalah.

Pemerintah sekarang sudah mulai memperhatikan UMKM karena tidak bisa dipungkiri bahwa UMKM menyumbangkan angka yang besar terhadap PDB, sehingga pemerintah berupaya membantu pelaku UMKM untuk dapat berkembang. Hal tersebut sejalan dengan pendapat dari Nawai dan Shariff (2011), kredit sangat penting untuk pengembagan usaha. Bantuan kredit yang berasal dari lembaga keuangan dapat dimanfaatkan pelaku UMKM untuk digunakan dalam kegiatan produktif guna mengembangan usahanya. Hal tersebut diperkuat hasil penelitian Menurut Fatoki, Asah (2011) dan Oyi, Daniya yang dikutip oleh Gulani dan Usman (2012) bahwa, tambahan modal diperlukan untuk memfasilitasi pengembangan usaha seperti pengembangan produk memperluas tempat usaha dan menambah tenaga kerja atau fasilitas produksi.

Penambahan modal kerja secara kredit yang diberikan oleh lembaga keuangan tidak serta merta membuat pelaku UMKM akan mampu mengembangkan usahanya. Penggunaan tambahan modal usaha harus digunakan dalam kegiatan produktif supaya mampu meningkatkan nilai barang maupun jasa yang dihasilkan UMKM. Peningkatan nilai barang maupun jasa akan memberikan efek terhadap pendapat yang diterima pelaku UMKM, sehingga pelaku UMKM dapat menjalankan kewajibannya. Pemberian tambahan modal secara kredit mempunyai kewajiban yang harus dilaksanakan oleh pelaku UMKM misalnya pembayaran cicilan dari pinjaman kredit setiap bulannya.

Peningkatan pendapatan yang berasal dari penambahan modal secara kredit juga mampu meningkatkan kesejahteraan pelaku UMKM. Hal tersebut diperkuat oleh pendapat Cheruiyot, Kimeli, Ogendo (2012: 50) menyatakan bahwa kredit Koperasi memainkan peran pen- ting dalam sosial ekonomi pengembangan masyarakat, mereka menyediakan jalan bagi anggota untuk menyimpan secara teratur dan kemudian meminjam untuk tujuan produktif dan kesejahteraan.

Pengelolaan modal usaha baik yang berasal dari lembaga keuangan secara kredit atau dari modal pribadi membutuhkan sebuah keterampilan. Keterampilan tersebut tidak hanya dalam penggunan modal tetapi juga harus mampu secara tepat menempatkan tambahan modal di dalam sebuah usaha. Berikut ini merupakan pendapat tentang pengertian dari kemampuan manajerial menurut Karweti (2010: 12) menyatakan bahwa Kemampuan manajerial adalah seperangkat keterampilan teknis dalam melaksanakan tugas sebagai manajer untuk mendayagunakan segala sumber yang tersedia untuk mencapai tujuan usaha secara efektif dan efisien. Sambasivan (2012: 58) menyatakan bahwa, "Managerial competencies are the skills, attributes and behaviours which are considered essential for staff with managerial or supervisory responsibilities". (Kompetensi manajerial adalah keterampilan, sifat dan tingkah laku yang dianggap penting bagi para staf dengan manajerial atau tanggung jawab pengawas).

Kemampuan manajerial adalah kemampuan untuk mengelola usaha seperti perencanaan, pengorganisasian, pemberian motivasi, pengawasan dan penilaian (Siagian, 1997: 107). Berdasarkan pendapat di atas kemampuan manajerial merupakan kemampuan yang dapat ditingkatkan yang berhubungan dengan pengelolaan suatu bidang usaha secara tepat sesuai dengan kebutuhan sehingga menciptakan hasil yang optimal.

Di dalam kemampuan manajerial minimal diperlukan tiga macam bidang keterampilan. Menurut Katz dalam Damim (2002: 44) bahwa: kemampuan manajerial itu meliputi technical skill (kemampuan teknis), human skill (kemampuan hubungan kemanusiaan), dan conceptual skill (kemampuan konseptual). Selain itu kemampuan manajerial bisa dinilai dari 
jenang pendidikan maupun pengalaman dalam menjalankan suatu usaha. Pernyataan tersebut diperkuat pendapat Hisrich and Drnovsek seperti yang dikutip oleh Fatoki and Asah (2011: 173) menyatakan bahwa, "Managerial Competencies as measured by education, managerial experience, start-up experience and knowledge of the business positively impact on the performance of SMEs". (Kompetensi manajerial yang diukur dengan pendidikan, pengalaman manajerial, pengalaman memulai dan pengetahuan tentang bisnis positif berdampak pada kinerja usaha kecil dan menengah).

Leslie, Dalton, Ernst and Deal yang dikutip oleh Sambasivan (2012: 59) juga menguatkan pernyataan di atas, menyatakan bahwa:

"Managerial capabilities includes three major categories of skill; learning behaviours, resilience and business knowledge. Learning behaviour include the motivation and skill to work and learn across cultural differences, resilience refers to the ability to manage time and stress, faktors that might, be more salient in the management task. The third skill group 'business knowledge' represents knowledge of the business strategies and practices".

(Kemampuan manajerial mencakup tiga kategori utama dari keterampilan; perilaku belajar, ketahanan, dan pengetahuan bisnis. Perilaku belajar meliputi motivasi dan keterampilan untuk bekerja dan belajar di perbedaan budaya. Ketahanan mengacu pada kemampuan untuk mengelola waktu dan stres, faktor-faktor yang mungkin, akan lebih menonjol dalam tugas manajemen. Kelompok ketiga skill "pengetahuan bisnis" merupakan pengetahuan tentang strategi dan praktek bisnis).

Keterampilan maupun kemampuan pelaku UMKM juga merupakan salah satu faktor penting dalam kesuksesan sebuah usaha. Kemampuan tersebut dinamakan kemampuan manajerial yang merupakan kemampuan keterampilan teknis dalam melaksanakan tugas sebagai manajer untuk mendayagunakan segala sumber yang tersedia untuk mencapai tujuan usaha secara efektif dan efisien (Karweti, 2010: 12). Hal tersebut diperkuat pendapat dari Karweti (2010) dan Sambasivan (2012), kemampuan manajerial merupakan keterampilan yang dianggap penting seorang pemimpin dalam melaksanakan tanggungjawab guna mencapai tujuan usaha secara efektif dan efisien.

Berdasarkan uraian di atas muncul ketertarikan untuk meneliti tentang UKM yang ada di Kota Madiun. Pertimbangan pemilihan UKM sebagai objek penelitian tidak terlepas karena jumlah UKM sudah terdaftar di Desperindagkoppar Kota Madiun. Berdasarkan uraian dan pertimbangan di atas maka peneliti akan melakukan penelitian dengan judul Kontribusi Pemberian Kredit dan Kemampuan Manajerial Terhadap Tingkat Pendapatan UKM di Kota Madiun 2015. Tujuan dari penelitian ini untuk mengetahui:

1. Kontribusi pemberian kredit terhadap tingkat pendapatan UKM di Kota Madiun.

2. Kontribusi kemampuan manajerial terhadap tingkat pendapatan UKM di Kota Madiun.

3. Kontribusi pemberian kredit dan kemampuan manajerial secara bersama-sama terhadap tingkat pendapatan UKM di Kota Madiun.

\section{METODE PENELITIAN}

Penelitian ini dilakukan di Kota Madiun pada tahun 2014. Metode penelitian yang akan digunakan dalam penelitian ini adalah metode deskriptif analitis. Populasi dalam penelitian ini berjumlah 113 dan sampel dalam penelitian ini 90 dengan menggunakan teknik sampel propotionate stratified random sampling. Teknik pengumpulan data yang digunakan adalah kuesioner dan dokumentasi yang dimiliki kantor Disperindagkoppar Kota Madiun serta dianalisis dengan menggunakan analisis regresi linier berganda. Kontribusi pemberian kredit dan kemampuan manajerial terhadap tingkat pendapatan UKM di Kota Madiun sebagai berikut: 


\section{HASIL PENELITIAN DAN PEMBAHASAN}

\begin{tabular}{|c|c|c|c|c|c|c|}
\hline \multicolumn{7}{|c|}{ 1. TABEL UJI T } \\
\hline \multirow{2}{*}{\multicolumn{2}{|c|}{ Model }} & \multicolumn{2}{|c|}{ Unstandardized Coefficients } & \multirow{3}{*}{$\begin{array}{c}\text { Standardized Coefficients } \\
\text { Beta }\end{array}$} & \multirow{3}{*}{$\begin{array}{c}\mathbf{t} \\
1.188 \\
\end{array}$} & \multirow{3}{*}{$\begin{array}{l}\text { Sig. } \\
.238 \\
\end{array}$} \\
\hline & & B & Std. Error & & & \\
\hline \multirow{3}{*}{1} & (Constant) & 3.423 & 2.881 & & & \\
\hline & PK & .210 & .075 & .266 & 2.817 & .006 \\
\hline & $\mathrm{KM}$ & .299 & .069 & .410 & 4.348 & .000 \\
\hline
\end{tabular}

\section{TABEL UJI F}

\begin{tabular}{|c|l|c|c|c|c|c|}
\hline \multicolumn{7}{|c|}{ ANOVA } \\
\hline \multirow{3}{*}{1} & Model & Sum of Squares & df & Mean Square & F & Sig. \\
\hline \multirow{2yyyyyy}{*}{1} & Regression & 72.618 & 2 & 36.309 & 19.792 & $.000^{\text {b }}$ \\
\cline { 2 - 7 } & Residual & 159.604 & 87 & 1.835 & & \\
\cline { 2 - 7 } & Total & 232.222 & 89 & & & \\
\hline \multicolumn{2}{|l|}{ a. Dependent Variable: TP } \\
\multicolumn{2}{|l|}{ b. Predictors: (Constant), KM, PK }
\end{tabular}

Berdasarkan perhitungan pada tabel 1, harga $t$ hitung pemberian kredit terhadap tingkat pendapatan sebesar 2,817 dengan signifikansi 0,006. Karena harga signifikansi $<0,05$, maka Ho ditolak dan disimpulkan terdapat pengaruh parsial pemberian kredit terhadap tingkat pendapatan. Artinya terdapat kontribusi pemberian kredit terhadap tingkat pendapatan UKM. Berdasarkan perhitungan pada tabel 1, harga t hitung kemampuan manajerial terhadap tingkat pendapatan sebesar 4,348 dengan signifikansi 0,000. Karena harga signifikansi $<0,05$, maka Ho ditolak dan disimpulkan terdapat pengaruh parsial kemampuan manajerial terhadap tingkat pendapatan. Artinya terdapat kontribusi kemampuan manajerial terhadap tingkat pendapatan UKM.

Berdasarkan perhitungan pada tabel 2, ma$\mathrm{ka}$ dapat diperoleh kesimpulan nilai $\mathrm{F}$ sebesar 19,792 dan signifikan pada $0,00<0,05$, maka dapat disimpulkan bahwa terdapat kontribusi pemberian kredit, kemampuan manajerial secara bersama-sama terhadap tingkat pendapatan. Berdasarkan pernyataan di atas ke dua variabel bebas mempunyai kontribusi variabel terikat yang artinya variabel pemberiankredit dan kemampuan manajerial bersama-sama mempunyai kontribusi terhadap tingkat pendapatan.

\section{KESIMPULAN DAN SARAN KESIMPULAN}

Berdasarkan perumusan masalah, tujuan penelitian, pengajuan hipotesis, hasil analisis dan pembahasan terhadap data penelitian yang telah dipaparkan pada bab sebelumnya, maka dapat ditarik kesimpulan sebagai berikut:

1. Terdapat kontribusi positif dan signifikan pemberian kredit terhadap tingkat pendapatan. Artinya bahwa jika sebuah UKM mendapatkan kredit akan berkontribusi terhadap tingkat pendapatan.

2. Terdapat kontribusi positif dan signifikan kemampuan manajerial terhadap tingkat pendapatan. Artinya bahwa jika kemampuan manajerial seorang pelaku usaha akan berkontribusi terhadap tingkat pendapatan.

3. Terdapat kontribusi positif dan signifikan pemberian kredit dan kemampuan manajerial secara bersama-sama terhadap tingkat pendapatan UKM. Hal tersebut memiliki makna bahwa masing-masing variabel pemberian kredit dan kemampuan manajerial memiliki kontribusi terhadap tingkat pendapatan

\section{SARAN}

Berdasarkam analisis dan kesimpulan di 
atas, maka berikut ini akan disampaikan saransaran kepada para pemangku kepentingan yang berkaitan, sebagai berikut:

\section{Pemerintah}

Bagi pemerintah pusat maupun pemerintah daerah khususnya di Kota Madiun diharapkan lebih meningkat peran serta dalam peningkatan pendapatan melalui pelatihan dan bantuan modal.

\section{Pelaku UKM}

Bagi para pelaku UKM, diharapkan pemanfaatan bantuan modal dari pemberian kredit yang diterima dapat dipergunakan secara optimal dan kemampuan para pelaku UKM perlu ditingkatkan melalui pelatihanpelatihan.

\section{Peneliti}

Diharapkan untuk penelitian selanjutnya menambahkan variabel-variabel lain agar hasil yang diperoleh akan lebih maksimal dan diharapkan pengambilan sampel yang digunakan dalam penelitian lebih diperbanyak, sehingga data lebih lengkap dari penelitian ini.

\section{DAFTAR PUSTAKA}

Cheruiyot, K, Kimeli, CM. and Ogendo, SM. 2012. Effect of Savings and Credit Cooperative Societies Strategies on Member's Savings Mobilization in Nairobi, Kenya. Journal of Business and Commerce.Vol. 1, No.11: 40-63.

Danim, S. 2002. Inovasi Pendidikan: Dalam Upaya Peningkatan Profesionalisme Tenaga Kependidikan. Bandung: Pustaka Setia.

Fatoki, O and Asah, F. 2011. The Impact of Firm and Entrepreneurial Characteristics On Access to Debt Finance by SMEs in King Williams' Town, South Africa. European Journal of Business and Management. Vol. 6, No. 8: 170-179.

Firdaus, R. dan Ariyanti, M. 2004. Manajemen Perkreditan Bank Umum. Bandung: Alfabeta.

Gulani, MG. and Usman, A. 2012. Financing
Small and Medium Scale Enterprises (Smes): A Challenge for Entrepreneurial Development in Gombe State. Asian Journal of Business and Management Sciences. Vol. 2 No. 9: 1723.

Ikatan Akuntan Indonesia. 2007. Standar Akuntansi Keuangan. Jakarta: Salemba Empat.

Karweti, E. 2010. Pengaruh Kemampuan Manajerial Kepala Sekolah dan Faktor yang Mempengaruhi Motivasi Kerja terhadap Kinerja Guru SLB di Kabupaten Subang. Jurnal Penelitian Pendidikan. Volume 11. Nomor 2.

Kuncoro, M. dan Suhardjono. 2011. Manajemen Perbankan. Yogyakarta: BPFE Yogyakarta.

Nawai, N. and Shariff, MNM. 2011. The Importance of Micro Financing to the Microenterprises Development in Malaysia's Experience. Journal Asian Social Science Vol. 7. No. 12: 226-238.

Sambasivan, E. 2012. Managerial Core Competency Perceptions of Business Executives a Study. Journal of Arts, Science \& Commerce. Vol. III, Issue 2(3): 56-63.

Siagian, SP. 1997. Teori Motivasidan Aplikasinya. Jakarta: Rineka Cipta.

Tjoekam, MH. 2002. Perkreditan Bisnis Inti Bank Komersial. Jakarta: Gramedia. 